\title{
Analyses of OJIP transients in leaves of two epiphytic orchids under drought stress
}

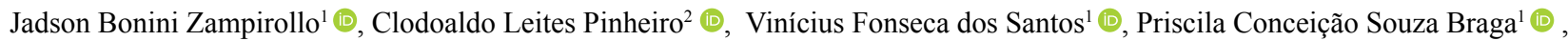

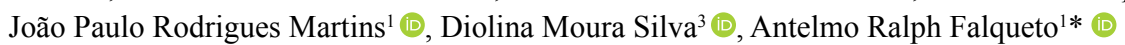 \\ (1) Universidade Federal do Espírito Santo, Departamento de Ciências Agrárias e Biológicas, São Mateus-ES, Brazil. \\ (2) Embrapa Pecuária Sul, Laboratório de Agroecologia e Recursos Naturais, Bagé-RS, Brazil. \\ (3) Universidade Federal do Espírito Santo, Departamento de Ciências Biológicas, Vitória-ES, Brazil.
}

\begin{abstract}
The tolerance to low water availability is a decisive factor for growth and survival of orchids in their natural environment. The objective of this study was to characterize the photochemical traits of two epiphytic orchids (Cattleya warneri and Miltonia spectabilis) under water deficit (WD). Chlorophyll $a$ fluorescence signals were recorded from young and fully expanded leaves of 5 plants/ species after dark-adaption for 60 minutes, between 6-9 a.m. after 0, 30, 60, and 90 days of WD, using a Handy-PEA fluorometer (Hansatech, UK). Increases of O-J and J-I phases and L and K-bands and decreases of I-P phase were observed after 30 days of WD, especially in $C$. warneri. Decreases in the capacity to photochemically reduce quinone $A\left(Q_{A}\right)$ and the kinetic properties required for redox reactions of the plastoquinone pool, the loss of energetic connectivity between units of PSII, inactivation of the oxygen evolution complex, and decrease of the overall rate of reducing the electron acceptor pool of photosystem I were observed in $M$. spectabilis, a more tolerant species. The greater ability of this species to maintain higher relative water content (RWC) in photosynthetic tissues allows greater photochemical activity.
\end{abstract}

Keywords: Cattleya warneri, Miltonia spectabilis, chlorophyll a fluorescence, K-band, photosystem II.

\section{Resumo}

Análise dos transientes OJIP em folhas de duas orquídeas epífitas submetidas ao estresse hídrico

A tolerância à baixa disponibilidade hídrica é fator decisivo para o crescimento e sobrevivência das orquídeas em seu ambiente natural. O objetivo deste estudo foi caracterizar os atributos fotoquímicos de duas orquídeas epífitas (Cattleya warneri e Miltonia spectabilis) sob déficit hídrico (WD). A fluorescência da clorofila $a$ foi registrada em folhas jovens e totalmente expandidas de 5 plantas/espécie adaptadas ao escuro por 60 minutos, entre 6 e $9 \mathrm{~h}$ da manhã, a 0, 30, 60 e 90 dias de WD, usando um fluorômetro Handy-PEA (Hansatech, Reino Unido). Aumentos nas fases O-J e J-I, bandas L e K e diminuição da fase I-P foram observados após 30 dias de $\mathrm{DW}$, principalmente em $C$. warneri. A diminuição da capacidade de redução da quinona $\mathrm{A}\left(\mathrm{Q}_{\mathrm{A}}\right)$ e das propriedades cinéticas requeridas para reações redox do pool de plastoquinona, a perda de conectividade energética entre unidades de fotossistema II (FSII), a inativação do complexo de evolução do oxigênio e a manutenção da taxa global de redução do pool aceptores de elétrons do fotossistema I foram observadas em M. spectabilis, espécie evidentemente mais tolerante. A maior habilidade dessa espécie em manter o conteúdo relativo de água nos tecidos fotossintéticos permite maior atividade fotoquímica.

Palavras-chave: Cattleya warneri, Miltonia spectabilis, fluorescência da clorofila $a$, Banda K, fotossistema II.

\section{Introduction}

Among abiotic factors, low precipitation is among the environmental factors with the greatest negative effect on the survival of epiphytic plants. Rainfall can be highly variable in space and time, thus affecting plant-water relationships (Grzesiak et al., 2019; Guevara-Perez et al., 2019). Overall, the low growth of plants in environments with low precipitation is probably due to physiological stress factors, such as low photosynthetic rate of chlorotic leaves.

Previous studies have often found diminished fitness of plants growing under low precipitation in relation to well-watered plants. Among the main physiological disturbances caused by water deficit are lower cell turgidity, variations of stomatal opening and chloroplast structure, and decreased transpiration and $\mathrm{CO}_{2}$ assimilation rate (Lang et al., 2018). Reduced $\mathrm{CO}_{2}$ assimilation can 
result in damage to photosystem II (PSII) reaction centers (RC), and consequently upset the equilibrium between photochemical activity of PSII and electron requirement for photosynthesis, generating over-excitation of the photosynthetic apparatus and photoinhibitory damage to PSII RC, in turn reducing the functional state of the photosynthetic apparatus (Pollastrini et al., 2017). Several research groups have reported the negative influence of water deficit on the physiological and photosynthetic properties of orchid plants (Guevara-Pérez et al., 2019; Li and Zhang, 2019; Tay et al., 2019).

Short rainless periods are common in Brazil, such as in northern Espírito Santo State, which typically has 3-4 months of drought every year. In this period, epiphytes are subject to changes in ecological conditions, such as increased temperatures and reduced air humidity. Nevertheless, an evolutionary advantage of epiphyte plants is the capacity to utilize alternative sources of water such as fog and dew. According to Wu et al. (2018), fog contributes $20 \%$ or more of the total water input in cloud forests, including the water used by orchids. However, these water sources are usually not enough to maintain positive water balance in plants during low precipitation seasons.

In vivo chlorophyll $a$ fluorescence $(\mathrm{Chl} a \mathrm{~F})$ measurements have been widely used to evaluate the functional state of the photosynthetic apparatus, especially PSII, providing useful physiological indicators to study plants' sensitivity to abiotic stress (Borawska-Jarmulowicz et al., 2020). It is possible to differentiate between drought-resistant and drought-sensitive species using $\mathrm{Chl} a \mathrm{~F}$ measurements as well as to identify the action site of stress on the photosynthetic electron transport chain (Oukarroum et al., 2016; Falqueto et al., 2017; Kalaji et al., 2018).

Considering that water availability is the abiotic factor that most affects the physiological traits of epiphytes, in this study we assumed that relative water content and in vivo $\mathrm{Chl} a \mathrm{~F}$ would be important traits to differentiate adaptive strategies of the photosynthetic apparatus in orchid plants growing under water stress conditions. Finally, we expected the regulation of specific steps of photosynthetic electron transport to indicate different levels of drought resistance among species. Our objective was to characterize the photochemical traits of two epiphytic orchids (Cattleya warneri T. Moore. and Miltonia spectabilis Lindl.), both evolved to cope with water deficit. We were interested in obtaining new information to better understand the adaptive strategies of epiphytic orchids to water deficit.

\section{Material and Methods}

\section{Plants, growth conditions, and drought treatment}

The experiment was performed using plants of two orchid species [Cattleya warneri T. Moore. and Miltonia spectabilis Lindl., CAM and $\mathrm{C}_{3}$ species, respectively, according to Adelberg et al. (1998) and Pires et al. (2012)], which are very common epiphytic orchids in Brazil. The plants were obtained from a commercial nursery and were planted in 2-liter plastic pots (one plant per pot) containing pine bark + carbonized rice husk, mixed at the ratio of $1: 1$ and maintained in greenhouse conditions $\left(18^{\circ} 43^{\prime} 0\right.$ ' $\mathrm{S}$; $39^{\circ} 51^{\prime} 34^{\prime \prime} \mathrm{W}$ ) for acclimation. The photoperiod (light/ dark) and relative air humidity in the greenhouse were $14 / 10 \mathrm{~h}$ and $75 \%$, respectively. The plants were subjected to two different irrigation treatments: $50 \%$ of the plants were maintained under water deficit (non-irrigated plants) and $50 \%$ were maintained in well-watered conditions (control, manually irrigated daily by adding $300 \mathrm{~mL}$ of water). All plants were protected against bacterial pathogens and weed competition. Water deficit was imposed by completely removing irrigation. The plants remained under persistent drought for 90 days. All measurements were performed in the morning (between 6-9 a.m.) every 30 days up to 90 days of water deficit ( 0 , 30,60 , and $90 \mathrm{~d}$ of WD).

\section{Leaf relative water content (RWC)}

Leaf RWC was measured as previously described by Barrs and Weatherley (1962). Five leaf discs per plant (diameter $0.6 \mathrm{~cm}$ ) were sampled and immediately weighed (fresh mass-FM). Then they were immersed in distilled water in Petri dishes for $24 \mathrm{~h}$ at $25^{\circ} \mathrm{C}$ under a photon flux density of $40 \mu \mathrm{mol} \mathrm{m} \mathrm{m}^{-2} \mathrm{~s}^{-1}$ on filter paper and the turgid mass (TM) was determined. Next, the discs were dried in an oven at $70{ }^{\circ} \mathrm{C}$ for 48 -h, until reaching constant weight, showing no water in the tissue, to obtain the dry mass (DM). RWC was calculated using the following equation: $\mathrm{RWC}=(\mathrm{FM}-\mathrm{DM}) /(\mathrm{TM}-\mathrm{DM}) \times 100$. The results were expressed in percentage $(\%)$.

\section{Chl $\boldsymbol{a}$ fluorescence transient (ChlaF)}

$\mathrm{Chl} a \mathrm{~F}$ measurements were conducted on young and fully expanded leaves (second leaf from the apex) at room temperature using a plant efficiency analyzer (Handy-PEA, Hansatech, King's Lynn, Norfolk, England) as described by Kalaji et al. (2018). Before the measurements, the leaf samples were dark-adapted using leaf clips (Hansatech, UK) for 60 minutes to promote total oxidation of the photosynthetic system. The fast Chla $\mathrm{F}$ kinetics (Fo to Fm) was induced by $1 \mathrm{~s}$ pulses of red light [650 nm, 3000 $\mu$ mol(photons) $\mathrm{m}^{-2} \mathrm{~s}^{-1}$, which was sufficient to generate maximal fluorescence for all the treatments. " $\mathrm{O}$ " refers to the initial minimal fluorescence level $\left(\mathrm{F}_{0}\right) ; \mathrm{P}(\approx 300 \mathrm{~ms})$ is the peak; and $\mathrm{J}(\approx 2$ to $3 \mathrm{~ms})$ and $\mathrm{I}(\approx 30 \mathrm{~ms})$ are inflection points between the $\mathrm{O}$ and $\mathrm{P}$ levels. All normalizations of the Chl $a \mathrm{~F}$ transients were carried out according to Yusuf et al. (2010). The variable relative fluorescence between $\mathrm{O}(50 \mu \mathrm{s})$ and $\mathrm{P}(300 \mathrm{~ms})$ steps was normalized as $\mathrm{V}_{\mathrm{t}}=$ $\left(\mathrm{F}_{\mathrm{t}}-\mathrm{F}_{0}\right) /\left(\mathrm{F}_{\mathrm{P}}-\mathrm{F}_{0}\right)$ and $\Delta \mathrm{V}_{\mathrm{t}}=\left[\mathrm{V}_{\mathrm{t} \text { (treatment) }}-\mathrm{V}_{\mathrm{t} \text { (control) }}\right]$. The I-P phase was analyzed utilizing two different normalization procedures: $\mathrm{V}_{\mathrm{OI}} \geq 1$ [normalization between $\mathrm{O}$ - and I-steps, only the part with $\mathrm{V}_{\mathrm{OI}} \geq 1$ ] and $\mathrm{V}_{\mathrm{IP}}$ [normalization between I- and P-steps]. The kinetic difference $\Delta \mathrm{V}_{\mathrm{IP}}$ was calculated as $\Delta \mathrm{V}_{\mathrm{IP}}=\mathrm{V}_{\mathrm{IP} \text { (treatment) }}-\mathrm{V}_{\mathrm{IP}(\text { control) }}$ and is shown on a linear scale between 30 and $180 \mathrm{~ms}$. 


\section{Experimental design and data analyses}

The experimental design was completely randomized using two orchid species submitted to WD during 90 days. The experiment was performed with five replicates per treatment. The Biolyser 4HP software (Biolyser@ R. M. Rodriguez, Bioenergetics Laboratory, University of Geneva, Geneva, Switzerland, version 3.06) was used to obtain the OJIP transients, and Excel 2013 was used to plot the transient graphs. RWC data were submitted to analysis of variance to compare the days of DW for each species. For significant values, means were compared by the Tukey test at $\mathrm{P}<0.05$ and expressed followed by the standard error $( \pm \mathrm{SE})$ using the Sisvar ${ }^{\circledR}$ program (Ferreira, 2011).

\section{Results}

The RWC values decreased in both orchid species, from $92.7 \%$ and $93.3 \%$ to $45.8 \%$ and $54.4 \%$ after 90 days of water suppression in C. warneri and M. spectabilis, respectively, representing reductions of about $50.5 \%$ and $41.6 \%$ compared to WD-0 (Figure 1). Reductions of RWC occurred from WD30 in $C$. warneri and only from WD-60 in M. spectabilis, which maintained higher values from WD-30 to WD-90.

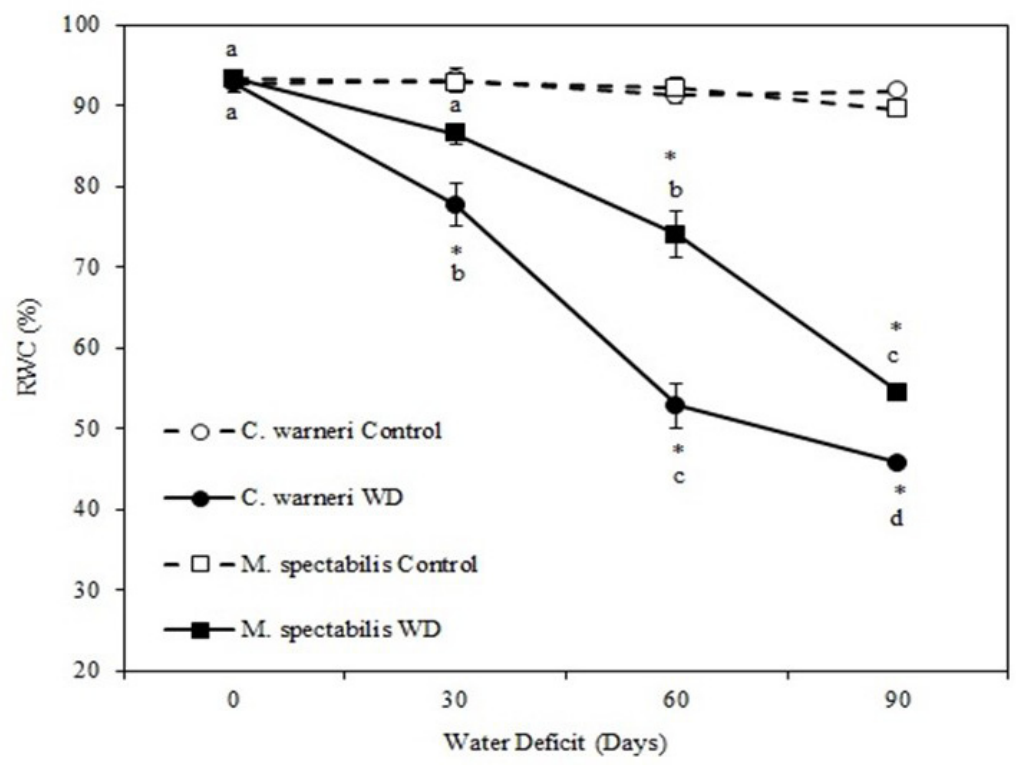

Figure 1. Relative water content (RWC) in Cattleya warneri and Miltonia spectabilis leaves subjected to water deficit (WD). Vertical bars indicate the standard error $( \pm \mathrm{SE})$. The letters indicate difference between the days of WD and the asterisks indicate difference between treatment and control by the Tukey test at $5 \%$ probability $(n=5)$.

Increases of the J-step were observed at 30 days of water deficit (WD-30) in both species and persisted until WD-90 (Figures 2A and 2B). However, the J-step values were higher in $C$. warneri. Also, a slight increase of the I-step occurred in $C$. warneri (Figure 2A). Furthermore, the analyses of $\Delta \mathrm{V}_{\mathrm{t}}$ evidenced the appearance of positive bands between the O-J and J-I phases (Figures 2C and 2D). This occurred from 30 days of water deficit (WD-30) onward in both orchid species. However, the amplitude of the curves was more positive in C. warneri (approximately $20 \%$ at WD-90) compared to $M$. spectabilis $(\approx 10 \%)$ (Figures $2 \mathrm{C}$ and $2 \mathrm{D})$. In $M$. spectabilis, the WD effects observed on ChlaF at WD-90 (maximum values obtained for this species) were similar to those observed at WD-30 in C. warneri (Figures $2 \mathrm{C}$ and 2D). 


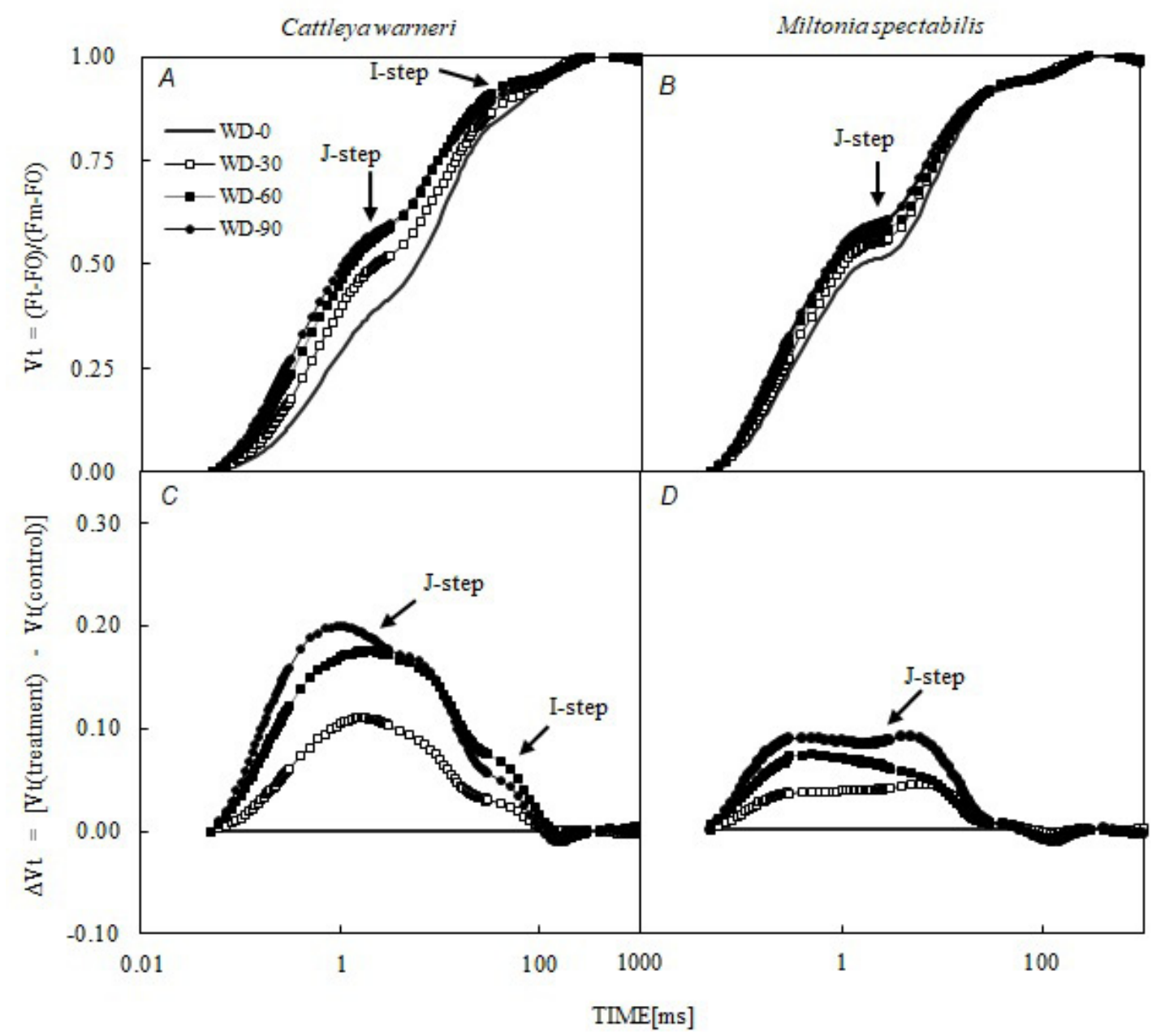

Figure 2. Kinetics of chlorophyll a fluorescence normalized between steps O-P in Cattleya warneri and Miltonia spectabilis submitted to water deficit (WD) for 90 days. Before the measurements, leaves were dark-adapted for $1 \mathrm{~h}$. Relative variable fluorescence $\mathrm{V}_{\mathrm{t}}=\left(\mathrm{F}_{\mathrm{t}}-\mathrm{F}_{0}\right) /\left(\mathrm{F}_{\mathrm{P}}-\mathrm{F}_{0}\right)(\mathrm{A}$ and $\mathrm{B})$, and kinetic difference of $\mathrm{V}_{\mathrm{t}}\left[\Delta \mathrm{V}_{\mathrm{t}}=\left[\mathrm{V}_{\mathrm{t}}\right.\right.$ (treatment $)-\mathrm{V}_{\mathrm{t}}($ control $\left.)\right](\mathrm{C}$ and $\mathrm{D})$. The values are means, $\mathrm{n}=5$.

In both species, the energetic connectivity (L-band) and stability of the oxygen evolution complex-OEC (K-band) decreased after WD-30 and reached a minimum on the day of maximum stress (approximately $12 \%$ and $18 \%$ in $C$. warneri and $\approx 8 \%$ and $\approx 9 \%$ in M. spectabilis for the L- and $\mathrm{K}$-bands, respectively) (Figure 3). However, in C. warneri, the increment observed in both L- and K-bands occurred gradually from WD-30 to WD-90 (Figures 3A and 3C). For M. spectabilis, the effects of water deficit on the energetic connectivity were grouped at two levels: 1- from WD-30 to WD-60 (characterized by similar L-band values) and 2WD-90 (where the maximum L-band value was recorded). 

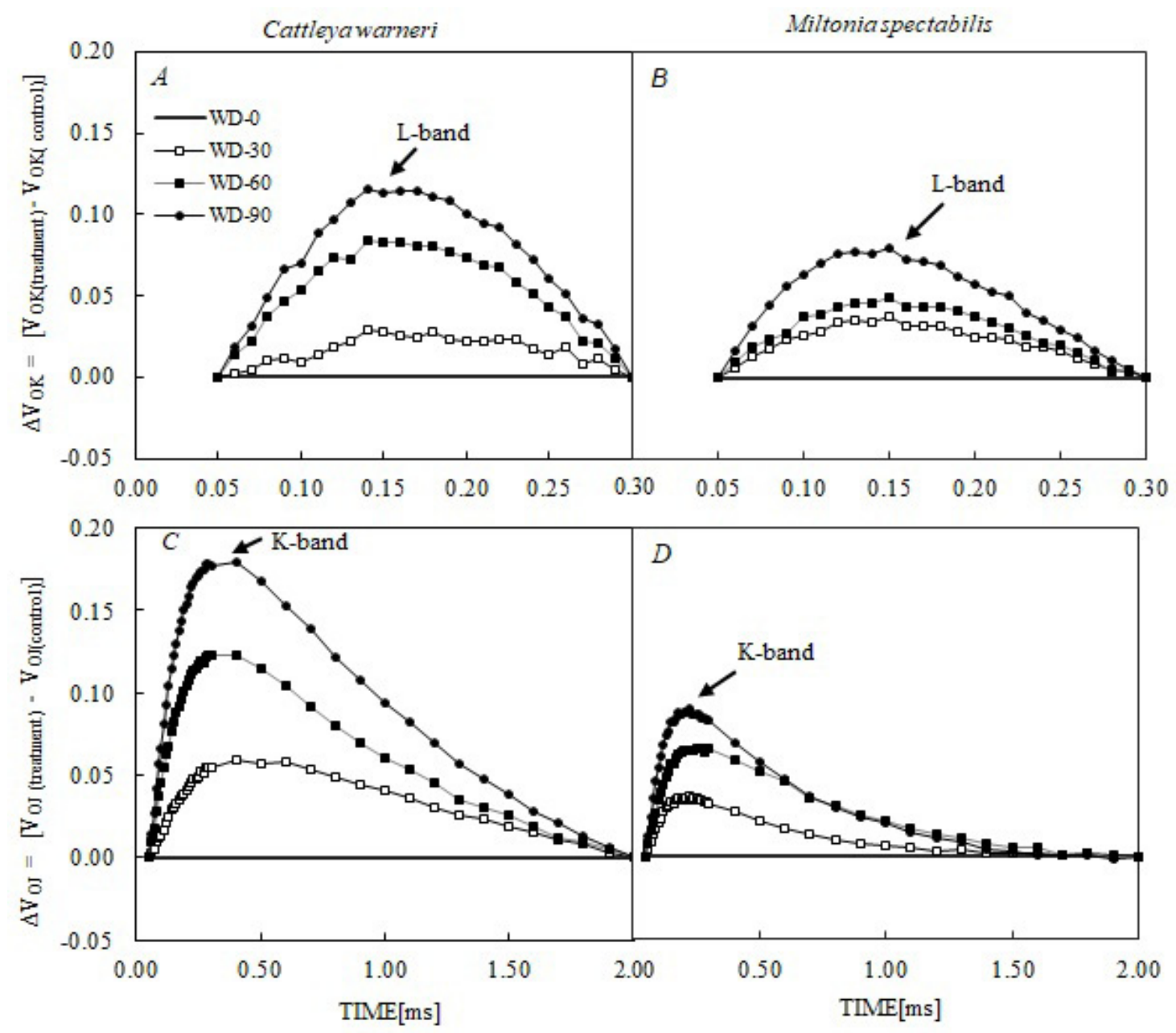

Figure 3. Kinetic differences of $\mathrm{V}_{\text {OK }}$ and $\mathrm{V}_{\text {OJ }}$ obtained after double normalization between the steps $\mathrm{O}-\mathrm{K}$ $\left[\Delta \mathrm{V}_{\mathrm{OK}}=\mathrm{V}_{\mathrm{OK}(\text { treatment }}-\mathrm{V}_{\mathrm{OK} \text { (control) }}\right](\mathrm{A}$ and $\mathrm{B})$, showing the $\mathrm{L}$-band, and between the steps $\mathrm{O}-\mathrm{J}\left[\Delta \mathrm{V}_{\mathrm{OJ}}=\mathrm{V}_{\mathrm{OJ} \text { (treatment) }}-\right.$ $\left.\mathrm{V}_{\mathrm{OJ}(\mathrm{control})}\right](\mathrm{C}$ and D), showing the K-band, respectively, in Cattleya warneri and Miltonia spectabilis submitted to water

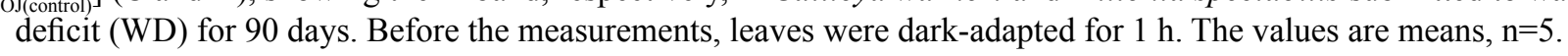

For C. warneri, the normalized curves of $\mathrm{V}_{\mathrm{OI}} \geq 1$ decreased with $\mathrm{WD}$, reaching minimum values at WD60 and WD-90 (Figure 4A). Conversely, no change in $\mathrm{V}_{\mathrm{OI}} \geq 1$ was recorded in M. spectabilis during the study (Figure 4B). The data normalized as $\mathrm{V}_{\mathrm{IP}}$ and $\Delta \mathrm{V}_{\mathrm{IP}}$ declined in both species in relation to WD-0. At WD90 , the $\mathrm{V}_{\mathrm{IP}}$ and $\Delta \mathrm{V}_{\mathrm{IP}}$ values were similar between species (Figures 4C-F). 

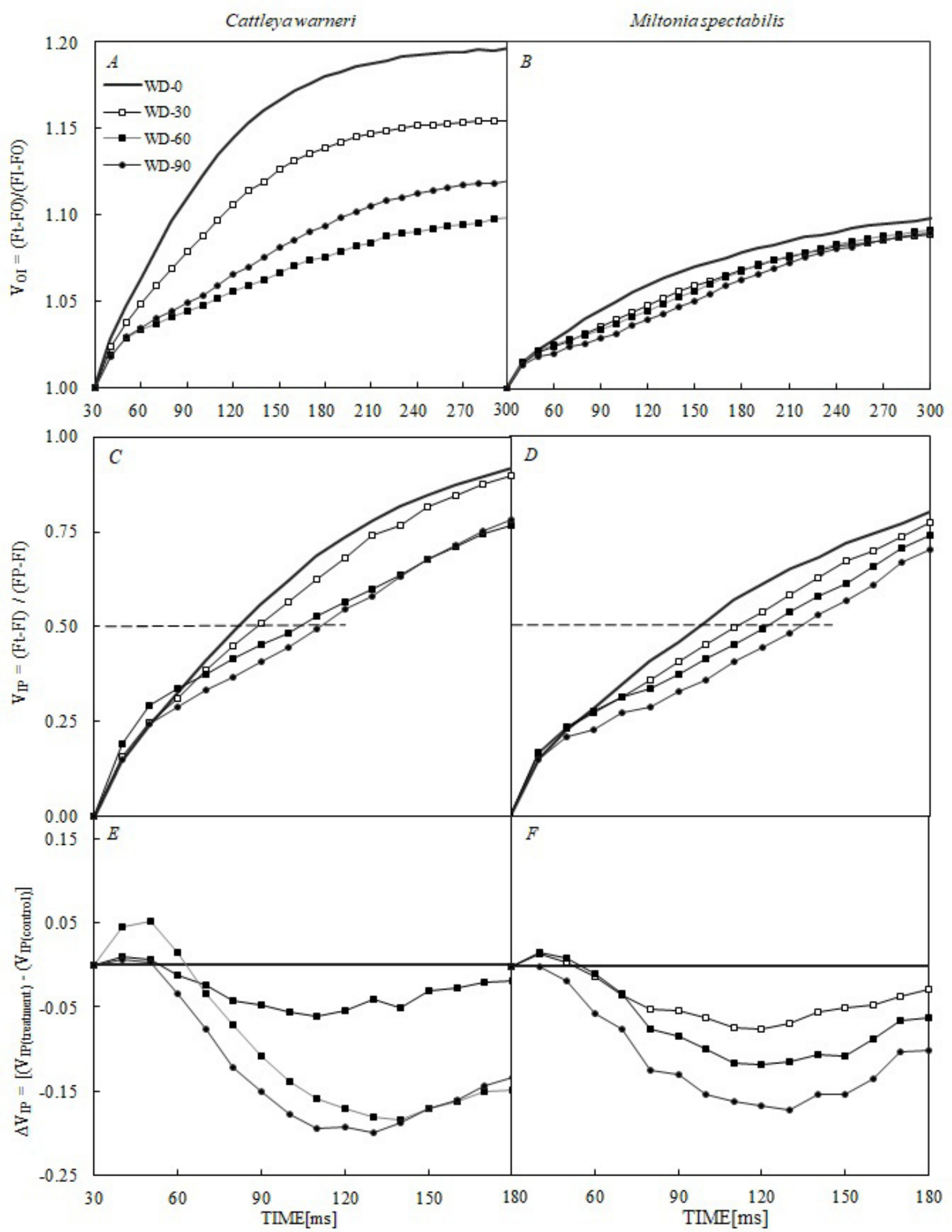

Figure 4. Kinetics of chlorophyll $a$ fluorescence normalized between steps O-I and I-P of Cattleya warneri and Miltonia spectabilis plants submitted to water deficit (WD) for 90 days. Before the measurements, leaves were darkadapted for $1 \mathrm{~h}$. Relative variable fluorescence between the steps O-I $\left[\mathrm{V}_{\mathrm{OI}}=\left(\mathrm{F}_{\mathrm{T}}-\mathrm{F}_{0}\right) /\left(\mathrm{F}_{\mathrm{I}}-\mathrm{F}_{0}\right)\right]$ in the interval between 30 and $300 \mathrm{~ms}(\mathrm{~A}$ and $\mathrm{B})$, relative variable fluorescence between the steps I-P $\left[\mathrm{V}_{\mathrm{IP}}=\left(\mathrm{F}_{\mathrm{t}}-\mathrm{F}_{\mathrm{I}}\right) /\left(\mathrm{F}_{\mathrm{P}}-\mathrm{F}_{\mathrm{I}}\right)\right](\mathrm{C}$ and D). The dashed lines indicate the half-life, the inverse of the time to reach $\mathrm{V}_{\mathrm{IP}}=0.5$, as described by the Michaelis-Menten equation), and kinetic differences of $\mathrm{V}_{\mathrm{IP}}:\left[\Delta \mathrm{V}_{\mathrm{IP}}=\mathrm{V}_{\mathrm{IP} \text { (treatment) }}-\mathrm{V}_{\mathrm{IP}(\text { control) }}\right](\mathrm{E}$ and $\mathrm{F})$. The values are means, $\mathrm{n}=5$. 


\section{Discussion}

In this study, we compared the photochemical responses of leaves of two orchid species to WD in order to identify the action site of WD in the electron transport chain on the acceptor side of PSII. It is known that water stress results in damage to the photosynthetic apparatus and reductions of stomatal aperture, light absorption and biochemical reaction of $\mathrm{CO}_{2}$ fixation, as reported previously by Falqueto et al. (2017) and Martins et al. (2017). In this study, the ChlaF technique proved to be an efficient tool to identify the differences between species.

During the experiment, the plants submitted to WD showed common characteristics of this type of stress, such as wilting of leaves, which occurred around 60 days after water deprivation, reaching a maximum at around the 90 days in both orchid species. Also, leaf abscission occurred in M. spectabilis after 60 days of drought. Leaf abscission is considered an effective mechanism to prevent drought damage during periods of low water availability (Naidoo and Naidoo, 2018). Before abscission, senescence occurs. Senescence is initially deleterious, but is an important evolutionary process in plants' life cycle that contributes to their fitness, ensuring survival in certain niches. Furthermore, senescence and abscission can be considered important processes to maintain the relative water content, contributing to mobilization of water, as well as promoting exportation of reserve compounds from wilted and old leaves to young leaves after catabolic conversion of the cell materials accumulated during the leaf growth phase, as described by Yang et al. (2016). These compounds serve as nutrients to maintain young leaves.

The increases observed at the J-step in C. warneri and M. spectabilis and the I-step in C. warneri, with consequent appearance of a positive band in the O-J and J-I phases, are an indication of limited electron flux resulting from the accumulation of PSII acceptors $\left(Q_{A}, Q_{B}\right)$ and PQ pool in reduced forms (Zushi and Matsuzoe, 2017) (Figure 1). Increases in the J-step were also the main typical characteristics of the ChlaF transient OJIP in Augea capensis Thunb. and Zygophyllum prismatocarpum E. Meyer ex Sond, growing in the arid Namib Desert (Heerden et al., 2007). This increase of the J-step is attributed to the peak concentration of $Q_{A}{ }^{-} Q_{B}$ and $Q_{A}{ }^{-} Q_{B}{ }^{-}$originated from the electron transport chain, where electrons are transferred from $Q_{A}$ to $Q_{B}$ (Goltsev et al., 2016). This appears to be a common response of several species to environmental stress. As proposed by Redillas et al. (2011), this occurs because PSI is less tolerant to drought than PSII, so the efficiency of electron transport to PSI is lower and causes the accumulation of reduced forms $\left(\mathrm{Q}_{A}{ }^{-} \mathrm{Q}_{B}{ }^{-}\right)$. In the present study, we observed that starting at 30 days of WD there was accumulation of reduced forms of the intermediaries of the electron transport chain, limiting the photochemical flow between PSII and PSI in both species (Xin et al., 2013). However, this limitation was more clearly observed in $C$. warneri, despite the characteristic leaf of this orchid species. This result is surprising, since higher tolerance is expected of CAM plants compared to $\mathrm{C}_{3}$ plants when exposed to water stress (Niechayev et al., 2019). Those authors reported that plants with both $\mathrm{C}_{3}$ and CAM metabolism are susceptible to the effects of water deficit, but the influence of water deficit on the photochemical activity was revealed previously to be stronger in $\mathrm{C}_{3}$ than CAM plants. Moreover, the similar values of $\Delta \mathrm{V}_{\mathrm{t}}$ observed between WD-90 for $M$. spectabilis and WD-30 for $C$. warneri revealed that $M$. spectabilis is better able to photochemically reduce $\mathrm{Q}_{\mathrm{A}}$ and maintain the kinetic properties required for reduction/ oxidation of plastoquinone under WD. This fact may be related to the better ability to preserve the relative water content of the leaves for a longer period in M. spectabilis.

Also, the analyses of the $\mathrm{Chl} a \mathrm{~F}$ transient allowed us to identify the appearance of L- and K-bands. According to Oukarroum et al. (2016), under drought stress, the appearance of both L- and K-bands should be a good indicator of physiological disturbances before the manifestation of visual damage. The L-band (150 $\mu \mathrm{s})$ is an indicator of energetic connectivity or grouping between the subunits of PSII and is related to maintenance of the structure/stacking of thylakoids in chloroplasts (Rosa et al., 2018). The L-band can assume positive or negative values, being more positive with lower energetic connectivity and less grouping of subunits (Yusuf et al., 2010). The results presented in Figures 3A and 3B show decreases in the energetic connectivity (positive L-bands) due to the effect of WD starting at 30 days (WD-30) in both C. warneri and M. spectabilis plants. This disturbance occurred gradually and was more pronounced in $C$. warneri, reaching values approximately $12 \%$ higher after 90 days of water deficit. On the other hand, in M. spectabilis, there was higher stability of energetic connectivity with water deficit, since the L-band values at 30 and 60 days were similar and only $5 \%$ higher compared to the control conditions (WD-0). Only at WD-90 did the L-band rise $(\approx 8 \%)$ in relation to the control. These results show that the effect of WD on the stability and energetic connectivity in the $\mathrm{C}_{3}$ species is more effective only after 60 days.

The presence of the K-band, which occurred around $300 \mu \mathrm{s}$, indicates the inactivation of OEC and/or increased antenna size of PSII (Yusuf et al., 2010). The pronounced K-band can be explained by energetic imbalance between the electron donor and acceptor sides in PSII, where the electron flow from OEC to $\mathrm{P}_{680}$ on the donor side of PSII is slower than the electron flow from PSII to $Q_{A}$ on the acceptor side (Yusuf et al., 2010; Santos et al., 2020). In this study, the increases observed in the K-band in both species can be attributed to the inactivation of the OEC, considering that the water stress caused the appearance of positive bands starting from WD-30. Regarding the K-band values, the effects of WD were more pronounced in $C$. warneri, in which a gradual increase of the K-band values was recorded during the WD period, reaching values $\approx 18 \%$ higher than those observed at WD-0 (Figure 3C).

Holland et al. (2015) reported that WD also reduced the energetic connectivity and caused inactivation of the OEC in plants of Agave salmiana and Quercus pubescens, respectively. In this study, the higher stability and energetic connectivity between subunits of PSII and the better OEC 
performance as well as the invariability of photochemical flow of electrons between PSII and PSI in M. spectabilis can be explained by the high RWC values found in this species. Another possible explanation is the occurrence of photorespiration in $M$. spectabilis $\left(\mathrm{C}_{3}\right.$ species $)$. Photorespiration is characterized by increased oxygenation rates of Rubisco and decreased carboxylation rates, resulting in decreased photosynthesis. The photorespiratory pathway stimulates the utilization of photons when the $\mathrm{CO}_{2}$ supply is limited by WD, consuming ATP and reducing energy use, protecting the photosynthetic apparatus against oxidative damages (Zhang et al., 2016).

The normalization between the I- and P-steps permits deducing the behavior of the electron transfer from the intersystem to the end electron acceptors of PSI. As described by the Michaelis-Menten equation, $\mathrm{V}_{\mathrm{IP}}=0.5$ (highlighted with dashed lines in Figures 4C and 4D) is the half-life, the inverse of the time to reach $\mathrm{V}_{\mathrm{IP}}=$ 0.5 , defined as an estimate of the global rate of reduction of the end electron acceptors of PSI (Yusuf et al., 2010). In this study, we observed decreased capacity of adjustment of the reduction process of the end electron acceptor of PSI, which can be directly responsible for the accumulation of reduced $\mathrm{Q}_{\mathrm{A}}{ }^{-}$in both species $(C$. warneri and $M$. spectabilis), as previously observed through analysis of the J-step.

Furthermore, these differences in adjustment of the reduction process associated with the end electron acceptor of PSI between days of WD can be observed more accurately by analyzing the kinetic differences $\Delta \mathrm{V}_{\mathrm{IP}}$ (Yusuf et al., 2010). Figures 4E and 4F show similar behavior between species, with progressive decrease of the regulation rate of the end electron acceptor reduction until WD-90 in $C$. warneri and M. spectabilis. Reductions in $\Delta \mathrm{V}_{\mathrm{IP}}$ were described by Jiang et al. (2008) in Citrus grandis plants under aluminum (Al) stress and by Yusuf et al. (2010) in transgenic Brassica juncea plants submitted to salt, heavy metal and osmotic stress. As previously noted by Yusuf et al. (2010) and Redillas et al. (2011), the regulation of the global reduction rate of the electron acceptors $\left(\mathrm{V}_{\mathrm{IP}}\right.$ and $\left.\Delta \mathrm{V}_{\mathrm{IP}}\right)$ (Figures $4 \mathrm{C}$ and $4 \mathrm{~F}$ ) occurred independently of the regulation of the end electron pool size on the PSI acceptor side $\left(\mathrm{V}_{\mathrm{OI}}\right)$ (Figures $4 \mathrm{~A}$ and 4B). While in $C$. warneri there was decreased regulation of end electron acceptor reduction of PSI and the regulation of end electron pool size (Figures 4A, 4C and 4E) under WD, M. spectabilis had decreases only of the regulation of end electron acceptor reduction of PSI (Figures 4B, 4D and 4F).

\section{Conclusions}

In conclusion, the photosynthetic apparatus of $M$. spectabilis was more tolerant to WD than that of $C$. warneri, as shown mainly through of activities related to PSII and the intersystem ( $\Delta \mathrm{V}_{\mathrm{T}}$ curves, $\mathrm{K}$ and L-bands). Although the regulation of end electron pool size differed between the species, the similarity of regulation of end electron acceptor reduction of PSI showed that the distinct behavior between the species was restricted specifically to the behavior of PSII. The result found in this study can be attributed to the photoprotective role of photorespiration in the photosynthetic apparatus, but especially was due to the better ability of $\mathrm{C}_{3}$ species to maintain higher relative water content (RWC) during the experiment. More water in photosynthetic tissues allows greater photochemical activity.

\section{Acknowledgments}

We thank to Coordinate Improvement of Higher Education Personnel (CAPES) for fellowships. MSc. Jadson Bonini Zampirolo was supported by the Postgraduate Program of CAPES. This study was financed by National Council for Scientific and Technological Development (CNPq) and Research Innovation Support Foundation of Espírito Santo (EDITAL CNPq/FAPES No. 02/2011).

\section{Author Contribution}

JBZ: investigation, writing - original draft, formal analysis. CLP: investigation, writing original draft, formal analysis. VFS: investigation, writing - original draft, formal analysis. PCSB: Writing - original draft, formal analysis. JPRM: review, editing. DMS: review, editing, conceptualization, methodology. ARF: writing, review, editing, conceptualization, methodology.

\section{References}

ADELBERG, J.; POLLOCK, R.; RAJAPAKSE, N.; YOUNG, R. Micropropagation, decontamination, transcontinental shipping and hydroponic growth of Cattleya while sealed in semipermeable membrane vessels. Scientia Horticulturae, v.73, n.1, p.23-35, 1998. https:// doi.org/10.21273/HORTSCI.32.3.547A

BARRS, H.D.; WEATHERLEY, P.E. A re-examination of the relative turgidity technique for estimating water deficits in leaves. Australian Journal of Biological Sciences, v. 15, n.3, p.413-428, 1962. https://doi.org/10.1071/BI9620413

BORAWSKA-JARMUŁOWICZ, B., MASTALERCZUK, G., DĄBROWSKI, P., KALAJI, H.M., WYTRĄŻEK, K. Improving tolerance in seedlings of some Polish varieties of Dactylis glomerata to water deficit by application of simulated drought during seed germination. Photosynthetica, v.58, n.2, p.540-548, 2020. https://doi. org/10.32615/ps.2020.007

FALQUETO, A.R.; SILVA-JUNIOR, R.A.; GOMES, M.T.G.; MARTINS, J.P.R.; SILVA, D.M.; PARTELLI, F.L. Effects of drought stress on chlorophyll a fluorescence in two rubber tree clones. Scientia Horticulturae, v.224, p.238243, 2017. https://doi.org/10.1016/j.scienta.2017.06.019 
FERREIRA, D.F. Sisvar: a computer statistical analysis system. Ciência e Agrotecnologia, v.35, n.6, p.1039-1042, 2011. https://doi.org/10.1590/S1413-70542011000600001 GOLTSEV, V.N., KALAJI, H.M., PAUNOV, M., BĄBA, W., HORACZEK, T., MOJSKI, J., KOCIEL, H., ALLAKHVERDIEV, S.I. Variable chlorophyll fluorescence and its use for assessing physiological condition of plant photosynthetic apparatus. Russian Journal of Plant Physiology, v.63, n.6, p.869-893, 2016. https://doi.org/10.1134/S1021443716050058

GRZESIAK, S., HORDYŃSKA, N., SZCZYREK, P., GRZESIAK, M.T., NOGA, A., SZECHYŃSKA-HEBDA, M. Variation among wheat (Triticum easativum L.) genotypes in response to the drought stress: I-selection approaches. Journal of Plant Interactions, v. 14, n. 1, p.3044, 2019. https://doi.org/10.1080/17429145.2018.1550817

GUEVARA-PÉREZ, C.I.; DELGADO-SÁNCHEZ, P.; CASTILLO, J.A.T.; RIVAS, J.D.F.; LEIVA, G.M.; MANZANO, E.R. Epiphytic orchids Stanhopea tigrina and Prosthechea cochleata are differentially affected by drought in a subtropical cloud forest. Photosynthetica, v.57, n.4, p.1053-1065, 2019. http://doi.org/10.32615/ ps. 2019.123

HEERDEN, P.D.R.; SWANEPOEL, J.W.; KRUGER, G.H.J. Modulation of photosynthesis by drought in two desert scrub species exhibiting $\mathrm{C}_{3}$-mode $\mathrm{CO}_{2}$ assimilation. Environmental and Experimental Botany, v.61, n.2, p.124-136, 2007. https://doi.org/10.1016/j. envexpbot.2007.05.005

HOLLAND, V.; KOLLER, S.; LUKAS, S.; BRUGGEMANN, W. Drought- and frost-induced accumulation of soluble carbohydrates during accelerated senescence in Quercus pubescens. Trees, v.30, n.1, p.215226, 2015. https://doi.org/10.1007/s00468-015-1290-4

JIANG, H.X.; CHEN, L.S.; ZHENG, J.G.; HAN, S.; TANG, N.; SMITH, B.R. Aluminum-induced effects on Photosystem II photochemistry in Citrus leaves assessed by the chlorophyll $a$ fluorescence transient. Tree Physiology, v.28, n.12, p.1863-1871, 2008. https://doi.org/10.1093/ treephys/28.12.1863

KALAJI, H.M.; BĄBA, W.; GEDIGA, K.; GOLTSEV, V.; SAMBORSKA, I.A.; CETNER, M.D.; DIMITROVA, S.; PISZCZ, U.; BIELECKI, K.; KARMOWKSA, K.; DANKOV, K.; KOMPALA-BABA, A. Chlorophyll fluorescence as a tool for nutrient status identification in rapeseed plants. Photosynthesis Research, v.136, n.3, p.329-343, 2018. https://doi.org/10.1007/s11120-0170467-7

LANG, Y., WANG, M., XIA, J., ZHAO, Q. Effects of soil drought stress on photosynthetic gas exchange traits and chlorophyll fluorescence in Forsythia suspensa. Journal of Forestry Research, v.29, n.1, p.45-53, 2018. https://doi. org/10.1007/s11676-017-0420-9
LI, J.W.; ZHANG, S.B. Physiological responses of orchids pseudobulbs to drought stress are related to their age and plant life form. Plant Ecology, v.220, n.1, p.83-96, 2019. https://doi.org/10.1007/s11258-018-00904-X

MARTINS, R.F.A.; SOUZA, A.F.C.; PITOL, C.; FALQUETO, A.R. Physiological responses to intense water deficit in two genotypes of crambe (Crambe abyssinica Hochst.). Australian Journal of Crop Science, v.11, n.7, p.821-827, 2017. https://doi.org/10.21475/ ajcs.17.11.07.pne469

NAIDOO, G.; NAIDOO, K.K. Drought stress effects on gas exchange and water relations of the invasive weed Chromolaena odorata. Flora, v.248, p.1-9, 2018. https:// doi.org/10.1016/j.flora.2018.08.008

NIECHAYEV, N.A.; PEREIRA, P.N.; CUSHMAN, J.C. Understanding trait diversity associated with crassulacean acid metabolism (CAM). Current Opinion in Plant Biology, v.49, p.74-85, 2019. https://doi.org/10.1016/j. pbi.2019.06.004

OUKARROUM, A.; EL-GHAROUS, M.; GOLTSEV, V.; STRASSER, R.J. Delayed fluorescence emission as a probe for the response of photosynthetic organisms to high temperature exposure: a comparative study. Journal of Luminescence, v.180, p.321-327, 2016. DOI: https://doi. org/10.1016/j.jlumin.2016.08.061

PIRES, M.V.; ALMEIDA, A.A.F.; ABREU, P.P.; COSTA, S.D. Does shading explain variation in morphophysiological traits of tropical epiphytic orchids grown in artificial conditions? Acta Physiologiae Plantarum, v.34, n.6, p.2155-2164, 2012. https://doi.org/10.1007/s11738-0121016-9

POLLASTRINI, M.; NOGALES, A.G.; BENAVIDES, R.; BONAL, D.; FINER, L.; FOTELLI, M.; GESSLER, A.; GROSSIORD, C.; RADOGLOU, K.; STRASSER, R.J.; BUSSOTTI, F. Tree diversity affects chlorophyll a fluorescence and other leaf traits of tree species in a boreal forest. Tree physiology, v.37, n.2, p.199-208, 2017. https:// doi.org/10.1093/treephys/tpw132

REDILLAS, M.C.F.R.; STRASSER, R.J.; JEONG, J.S.; KIM, Y.S.; KIM, J.K. The use of JIP test to evaluate drought-tolerance of transgenic rice overexpressing OsNAC10. Plant Biotechnology Reports, v.5, n.2, p.169175, 2011. https://doi.org/10.1007/s11816-011-0170-7

ROSA, W.S.; MARTINS, J.P.R.; RODRIGUES, E.S.; RODRIGUES, L.C.A.; GONTIJO, A.B.P.L.; FALQUETO, A.R. Photosynthetic apparatus performance in function of the cytokinins used during the in vitro multiplication of Aechmea blanquetiana (Bromeliaceae). Plant Cell, Tissue and Organ Culture, v.133, n.3, p.339-350, 2018. https:// doi.org/10.1007/s11240-018-1385-x 
SANTOS, E.R.; MARTINS, J.P.R.; RODRIGUES, L.C.A.; GONTIJO, A.B.P.L.; FALQUETO, A.R. Morphophysiological responses of Billbergia zebrina Lindl. (Bromeliaceae) in function of types and concentrations of carbohydrates during conventional in vitro culture. Ornamental Horticulture, v.26, n.1, p.18-34, 2020. https://doi.org/10.1590/2447-536x.v26i1.2092

TAY, S.; HE, J.; YAM, T.W. CAM plasticity in epiphytic tropical orchid species responding to environmental stress. Botanical Studies, v.60, n.1, p.7, 2019. https://doi. org/10.1186/s40529-019-0255-0

WU, Y.; SONG, L.; LIU, W.; LIU, W.; LI, S.; FU, P.; SHEN, Y.; WU, J.; WANG, P.; CHEN, Q.; LU, H. Fog water is important in maintaining the water budgets of vascular epiphytes in an Asia Tropical Karst Forests during the dry season. Forests, v.9, n.5, p.260, 2018. https://doi. org/10.3390/f9050260

XIN, C.P.; YANG, J.; ZHU, X.G. A model of chlorophyll a fluorescence induction kinetics with explicit description of structural constraints of individual photosystem II units. Photosynthesis Research, v.117, n.1-3, p.339-354. 2013. https://doi.org/10.1007/s11120-013-9894-2
YANG, S.J.; SUN, M.; YANG, Q.Y.; MA, R.Y.; ZHANG, J.L.; ZHANG, S.B. Two strategies by epiphytic orchids for maintaining water balance: thick cuticles in leaves and water storage in pseudobulbs. Aob Plants, v.8, p, 1-11, 2016. https://doi.org/10.1093/aobpla/plw046

YUSUF, M.A.; KUMAR, D.; RAJWANSHI, R.; STRASSER, R.J.; TSIMILLI-MICHAEL, M; SARIN, N.B. Overexpression of $\gamma$-tocopherol methyl transferase gene in transgenic Brassica juncea plants alleviates abiotic stress: Physiological and chlorophyll a fluorescence measurement. Biochimica et Biophysica Acta, v.1797, n.8, p. 1428-1438, 2010. https://doi.org/10.1016/j.bbabio.2010.02.002

ZHANG, C.; ZHAN, D.X.; LUO, H.H.; ZHANG, Y.L.; ZHANG, W.F. Photorespiration and photoinhibition in the bracts of cotton under water stress. Photosynthetica, v.54, n.1, p.12-18, 2016. https://doi.org/10.1007/s11099-0150139-9

ZUSHI, K.; MATSUZOE, N. Using of chlorophyll a fluorescence OJIP transients for sensing salt stress in the leaves and fruits of tomato. Scientia Horticulturae, v.219, p.216-221, 2017. https://doi.org/10.1016/j. scienta.2017.03.016 